\title{
THE ROLE OF PEERS: SIBLINGS AND FRIENDS IN THE RECRUITMENT AND DEVELOPMENT OF ATHLETES
}

\author{
N.-F. Rønbeck ${ }^{1}$, N.O. Vikander ${ }^{2}$ \\ ${ }^{1}$ Finnmark University College, Alta, Norway \\ ${ }^{2}$ North Troendelag University College, Levanger, Norway
}

\begin{abstract}
The role of peers (siblings and friends) in the recruitment and development of cross country skiers was investigated using quantitative methodology. A questionnaire, constructed according to a Likert format, was employed to collect data on the 350 highest ranked cross country skiers on the International Ski Federation (FIS) point list (gender not a factor) representing the Norwegian Ski Association (NSF), and the United States Ski and Snowboard Association (USSA). Approximately half the athletes were from each country. For the purpose of data analysis respondents were classified into three performance levels based on the best self-reported results from very high level ski competitions. The broad consequences of the findings of the study direct attention to the necessity of viewing sport not only in its individual talent/physiology/biomechanics/psychology dimensions but also in its societal contexts. More specifically, athletic performances may be viewed as significantly mirroring total growing-up conditions and life situations, particularly with reference to the intimate primary group relations of family and friends, and as such can be a measuring rod for the efficacy of a society's social facilitation and policies.
\end{abstract}

Key words: talent, skiing, peers, recruitment, development. 


\section{INTRODUCTION}

A great deal of mythology has been spun about talent in sport. Generally the understanding of "talent" has been linked with genetic sources, much related to the idea of identifying talent already in childhood. Even today it is still argued that talents have been identified among children, as a forecast of future elite performers in sport. Despite the fact that some do succeed, the foundation for predicting this is thin. Neither personality nor identity are strongly anchored in the child as the basis for motivation and commitment, and neither is anything known of future resources for development in the interaction between personality and external access to resources. If the concept of talent is to be of use in serious dialogue and communication, then it is paramount that those involved have some commonality in their understanding of the term. In an attempt to clarify the issue, the following definition of talent is offered; a definition that guides the present work:

An athletic talent is characterized by the sporting achievements the individual has demonstrated as possessing the potential to reach, dependent on sufficient associated motivation, effort, and resources of varying type, size, and quality on an open-ended scale.

This means that there will always be discussion about the degree of talent. An unknown part of the talent's potential lies in the genes, whereof in many sports a number of concrete physiological parameters are known.

A highly talented performance level is, however, not only a result of inborn characteristics, but to the greatest degree a product of voluminous goal-directed training [8]. An optimization of this training is conditional on good motivation, great effort, and large resources of many kinds. The closely associated question then is how such motivation, effort, and resource-base emerge? While motivation and will to apply effort lie within the athlete, the resources needed are both of internal character in the athlete's personality, and of external character such as economy, knowledge, infrastructure, access to transport, equipment and materials of various types, etc. All these interact in dynamic fashion.

The absolutely fundamental condition for development of talent in sport is that the athlete-to-be is recruited to the athletic setting. This takes place in a social context composed of the family, and possibly a coach, in addition to the child [15]. The family's importance for the 
achievement of high performance-capacity has been in the spotlight in several studies including in a recent inquiry [13] where the parental role in the athlete socialization was investigated. The influence of siblings in the dynamics of the family is, however, a field that to a great extent has been overlooked in the study of sport. Although the same cannot be said of friends, even here there is a continued lack of a clear unraveling of their role.

From this point of departure, the following problem is addressed in the present investigation:

What role and consequence have siblings and friends in the recruitment and development of talents in the sport of cross country skiing?

The impetus for this query was the juxtaposition of several decades of intense experience by the authors with cross country skiing in Scandinavia and North America. How Scandinavia, in spite of its modest population, has historically dominated this sport, was a question that needed resolution. That there has not been a lack, in North America, of science-based knowledge of human performance variables, or a deficiency in technological competence or resources, was clear. Au contraire, reflection led to the socio-cultural arena in the search for answers, and in particular to the siblings within the family context, and beyond it to those significant others of children and youth, their friends. In Norway, success on the ski-trail has commonly been heavily viewed as an expression of socio-cultural forces, including politics and nation-building [4].

\section{REVIEW OF THE LITERATURE}

\section{Role-models in the Socialization to and within Sport}

If siblings and friends are felt as providing compelling demonstrations of inspiring behaviour, then children are drawn to identify with them. Through observation and acting like them, the children journey through a process of socialization towards a more anchored identity as an individual. Siblings and friends can through encouraging and rewarding behaviour in their settings together with other children and youth, contribute to constructive identity development. The study of such relationship dynamics formed the basis of the social-cognitive perspectives of Bandura [3]. The sum of habits, expectations, and interpretations of social contexts informed Bourdieu and Wacquant 
toward the concept of "habitus" (1992). The implication of this is that all that contributes to form the daily life of a family, such as social inheritance, social environment, relatives, and friends, will in sum connect the child to a culture or subculture. This is expressed through a familiar lifestyle of some form, and carries consequences for the relatively malleable children. It is therefore close at hand to expect a relationship between the athletic activities of siblings and friends in the recruitment of children to sport. It is suggested that this is an important element in forming the foundation for the further development of athletic talent.

Côté [7] proposed the existence of three defined stages in sportparticipation; the "sampling years" (6-13), the "specializing years" (14-15), and the "investment years" (over 15). An important condition for taking care of recruited children and preventing their dropping out from sport during their first development phase has been the feeling of joy and fun in sport, and the experience of growing skill-mastery through minimizing competition-stress [7, 10]. In the "investment years", however, the child would connect to only one sport. Training loads then grow to be extreme and disciplined, with performance at the elite level as the objective.

\section{The Role and Significance of Siblings}

In an in-depth study of the most internationally successful Norwegian athletes (6), two out of three in the top performance group indicated that their siblings had great or some importance for their personal athletic career. As many as three of four, moreover, had siblings who had large or moderate involvement in sport. In the control group which had not progressed as far along the career path, only barely one of three placed large or moderate significance on siblings for their career. All subjects in both groups had one or more siblings. A large majority in both groupings was the youngest or next-to-youngest among the siblings in the family.

The large-scale investigation by Eriksson [9] of Swedish national team members did not inquire about the importance of siblings, but nevertheless found that $94 \%$ had one or more siblings. However, it did not appear to matter where in the sequence of siblings the subjects were located. The distribution among oldest, in the middle, or youngest, was fairly even. In one of the larger, multidisciplinary, sports it appeared that a little brother/little sister role could to some 
degree be advantageous since a clear majority of respondents was the youngest sibling (in families of multiple siblings).

In Côté's [7] study it was concluded that sibling influence changed in concert with that of the parents in the progression through the three phases in athlete development. Throughout the "sampling years", all children in the family received the same support from the parents. However, during the "specialization years", parental attention and resource allocation gradually shifted more towards the athlete(s) in the family. This process received such distinct reinforcement in the "investment years" that it in some instances resulted in jealousies and bitterness among younger siblings where present. Nevertheless, in some families, older siblings were found to have a positive influence on the young athlete's decision to specialize in a given sport. This confirms that the role of the family must perforce be complex due to the manifold possible familial configurations.

Stevenson [16], in yet another study, concluded that siblings became important for the athlete in the later phases of development. They acted so as to take over the parents' influence as role-models.

\section{The Role and Significance of Friends}

The role of friends in children's socialization to sport is better known. Less understood is their influence on the development of an athlete's capacity for high performance.

The number of friends and their role appears to alter through the stages of development of an athlete towards the elite level. Abernethy, Wood, and Parks [1] found in a study of members of 15 Australian elite teams that all had had a group of friends involved in sport, early in their career. However, the meaning of having friends outside, as well as inside, sport became at least equally important during the "investment years". Through friends in sport, a great and important common link was established, while friends outside sport provided acknowledgement and appreciation for the athletic effort, while they simultaneously contributed to meeting the athlete's need to talk about things outside sport. It could appear that friends outside sport contributed to covering more complex social needs.

Breivik and Gilberg [6] found that fewer of their elite athlete subjects had friends who were active in the same sport as themselves, compared with the control group. However, it was not always so for these very top level athletes. In the beginning, many of these also had 
friends in sport. But advancing from 10 to 20 years of age, they progressively had fewer friends in sport, while a stable proportion of the control group retained theirs. The number of elite athletes who had friends active in their sport, sank from $75 \%$ to $50 \%$ over these years, while in the control group the figure stayed quite stable at ca. $70 \%$. Of the elite athletes, as many as two of three demonstrated considerable independence by indicating that they would continue with their sport regardless of whether their friends did or not. Still, concerning the importance their friends had for them, $61.1 \%$ of the elite placed large or some significance on their friends for their own personal continued effort in sport. Impressive as this effect of friends appears to be, it pales in comparison with the control group where fully $88.2 \%$ indicated their friends had large or some importance for their personal ongoing involvement in sport.

The research by Stevenson [16] showed that friends, like siblings, grew in influence in the later phases of athlete development, superseding the importance of parents.

In the Eriksson [9] study of the Swedish national team members, both parents and friends were main reasons why sport at all came into their life picture. However, here as well, it was the parents who were of consequence in the early period, while the friends relatively soon thereafter took over as the dominating causal social factor.

\section{MATERIALS AND METHODS}

\section{Quantitative Method}

A quantitative method through the use of questionnaire was employed due to the large number of subjects and their dispersed, international locations.

\section{Selection of Respondents}

The 350 highest ranked cross country skiers (gender not a factor) representing the Norwegian Ski Association (NSF), as well as of the United States Ski and Snowboard Association (USSA), were selected for the study, ca. half from each country. The selection criterion was placement on the International Ski Federation's (FIS) point list. 


\section{Access to Respondents}

Personal relationship with the administrative head of the NSF was instrumental in gaining access to contact information for the Norwegian athletes. In the United States, the contact information for the skiers was gained through the National Team coach (personally known from Norway).

\section{Questionnaire Construction}

The questionnaire was constructed according to a Likert format [2, 11]. The content had its foundation in the more than 40 years of experience in cross country skiing of each of the authors of the study. The elements of this background were personal competition experience as well as extensive work in the coaching role and in providing technical expertise from the local to the international level, as well as tertiary degrees in sport science with substantial focus on skiing. Personal research background contributing to the study's questionnaire construction included the development of the Behavior Inventories for Cross Country Skiers [14].

The response alternatives were scored on a scale of zero to five, depending on the degree of agreement, with 1 indicating complete disagreement and 5, complete agreement.

It was decided to include a neutral response alternative (nr. 3) despite a possible "pole-effect" [12] whereby some respondents may have a disposition to choose the first or last alternative in Likert-type questionnaires. A neutral alternative can enhance study validity in that some subjects may, in fact, not be able to respond any other way. In addition, the inclusion of a neutral alternative makes it possible to score questionnaires where respondents leave some items unanswered. In such cases, these items are scored according to the neutral response alternative.

Original questionnaire language was Norwegian, and translation into American English was carried out according to established research practice.

\section{Pilot Study}

The questionnaire was administered to cross country ski coaches and elite athletes, as well as researchers familiar with the sport, in Northwestern USA, Canada, and Norway. As a consequence of constructive feedback, changes were made in question formulations. 
The revised questionnaire was sent out again to the coaches and researchers for comment. These were then taken into account, and the final version was successfully tested on a university cross country ski team. Final layout modifications were suggested, and implemented.

\section{Collection of Data}

The questionnaire was distributed to 185 skiers in the USA and 165 skiers in Norway. Follow-up letters were sent two weeks later to those not yet responding.

\section{Response Rate}

The response rate in the USA was $57.8 \%$ (107 out of 185), and $65.5 \%$ in Norway (108 out of 165). Included among the respondents was $100 \%$ of the National Team in both countries.

\section{Statistical analysis}

The respondents were classified into three performance levels based on the best self-reported results from ski races at very high levels. Group 1 was composed of present and former National Team members with international high level performances. Group 2 skiers were below this performance level, while Group 3 was the lowest performing group.

This classification system resulted in the following athlete distribution among the three performance groups in the two countries:

\begin{tabular}{|l|c|c|c|}
\hline & Group 1 & Group 2 & Group 3 \\
\hline USA & 20 & 68 & 19 \\
\hline Norway & 37 & 46 & 25 \\
\hline
\end{tabular}

In the analysis of the data it was found to be appropriate for the purpose of clarity of result presentation and discussion to combine the response categories "Yes, I agree" with "Yes, I agree completely", as well as "No, I disagree" with "No, I disagree completely". 


\section{Quality Evaluation of the Study}

Reliability and validity were enhanced by the careful process of instrument construction based on the authors' long-term experience and with the assistance of expert advice from practitioner and scientific personnel. The multi-phase pilot testing of the questionnaire ensured thorough assessment on an empirical basis. For a more exhaustive examination concerning the quality of the materials and methods of the investigation, the reader is directed to the authors' recent cognate publication (13) which, like the present inquiry, was part of a larger-scale project.

\section{RESULTS}

The results of the study are presented under headings replicating item formulations in the questionnaire. In addition to the presentation of separate data in table form for each country, there is associated textual description. The question numbers refer to the numeration in the omnibus questionnaire for the broader investigation.

\section{1) My siblings were involved in sport or cross country skiing in my childhood.}

In Norway as many as $77.8 \%$ of the skier respondents "agreed" or "completely agreed" with this statement. The figure for the United States was somewhat lower, at $68.2 \%$.

Table 1a: Norway "In my childhood my siblings were engaged in cross country skiing" (question 3)

\begin{tabular}{|l|c|c|c|c|c|c|}
\hline $\begin{array}{l}\text { Likert scale } \\
\text { points }\end{array}$ & $\begin{array}{c}\text { Completely } \\
\text { disagree } \\
\text { (1) }\end{array}$ & $\begin{array}{c}\text { Dis- } \\
\text { agree } \\
\text { (2) }\end{array}$ & $\begin{array}{c}\text { Neither } \\
\text { agree nor } \\
\text { disagree } \\
\text { (3) }\end{array}$ & $\begin{array}{c}\text { Agree } \\
\text { (4) }\end{array}$ & $\begin{array}{c}\text { Completely } \\
\text { agree } \\
\text { (5) }\end{array}$ & Total \\
\hline Number of skiers & 14 & 3 & 7 & 22 & 62 & 108 \\
\hline $\begin{array}{l}\text { \% of total number } \\
\text { of skiers }\end{array}$ & 13.0 & 2.8 & 6.5 & $\mathbf{2 0 . 4}$ & $\mathbf{5 7 . 4}$ & 100.0 \\
\hline
\end{tabular}

Note: Percentage "agree" and "completely agree" in bold script are combined in the text. 
Table 1b: USA "In my childhood my siblings were engaged in cross country skiing" (question 3)

\begin{tabular}{|l|c|c|c|c|c|c|}
\hline $\begin{array}{l}\text { Likert } \\
\text { scale } \\
\text { points }\end{array}$ & $\begin{array}{c}\text { Completely } \\
\text { disagree } \\
\text { (1) }\end{array}$ & $\begin{array}{c}\text { Dis- } \\
\text { agree } \\
\text { (2) }\end{array}$ & $\begin{array}{c}\text { Neither } \\
\text { agree nor } \\
\text { disagree } \\
\text { (3) }\end{array}$ & $\begin{array}{c}\text { Agree } \\
\mathbf{( 4 )}\end{array}$ & $\begin{array}{c}\text { Completely } \\
\text { agree } \\
\text { (5) }\end{array}$ & Total \\
\hline $\begin{array}{l}\text { Number of } \\
\text { skiers }\end{array}$ & 25 & 1 & 8 & 26 & 47 & 107 \\
\hline $\begin{array}{l}\text { \% of total } \\
\text { number of } \\
\text { skiers }\end{array}$ & 23.4 & 0.9 & 7.4 & $\mathbf{2 4 . 3}$ & $\mathbf{4 3 . 9}$ & 100.0 \\
\hline
\end{tabular}

Note: Percentage "agree" and "completely agree" in bold script are combined in the text.

\section{2) My siblings had great significance for my development as a cross country skier.}

It should be noted that for this item, closely similar responses were given by the two countries on the "agreed/completely agreed" alternative; $34.2 \%$ in Norway, and $31.8 \%$ in the United States. However, the greatest density of responses was found among those reporting to "disagree" or to "completely disagree"; $47.2 \%$ in Norway and a substantially lower $38.4 \%$ in the United States. Those unsure ("neither agree nor disagree") were, in contrast, more numerous in the U.S., with $29.9 \%$, compared to $18.5 \%$ in Norway.

In the performance group analysis, only $25.0 \%$ of Group 1 in the United States "agreed" or "completely agreed" with the statement, while over the double incidence $(52.6 \%)$ of Group 3 skiers in that country responded in the same way. For Norway, the tendency is in the opposite direction, with $37.8 \%$ in Group 1, as contrasted to $28.0 \%$ of Group 3, reporting giving their siblings great significance. Unsure ("neither agree nor disagree") Group 1 athletes in the United States were as many as $35.0 \%$, whereas in Norway, only $16.2 \%$ of Group 1 responded in this manner. 
Table 2a: Norway "My siblings had great significance for my development as a cross country skier" (question 4)

\begin{tabular}{|c|c|c|c|c|c|c|}
\hline $\begin{array}{l}\text { Likert scale } \\
\text { points }\end{array}$ & $\begin{array}{c}\begin{array}{c}\text { Completely } \\
\text { disagree }\end{array} \\
\text { (1) }\end{array}$ & $\begin{array}{c}\begin{array}{c}\text { Disag } \\
\text { ree }\end{array} \\
(2) \\
\end{array}$ & \begin{tabular}{|c|} 
Neither \\
agree nor \\
disagree \\
(3)
\end{tabular} & $\begin{array}{c}\text { Agree } \\
\text { (4) }\end{array}$ & $\begin{array}{c}\text { Completely } \\
\text { agree } \\
\text { (5) }\end{array}$ & Total \\
\hline \multicolumn{7}{|l|}{ Groups of skiers } \\
\hline $\begin{array}{l}\text { Group 1 } \\
\text { (highest per- } \\
\text { formance } \\
\text { level): } \\
\text { - number of } \\
\text { skiers } \\
\text { \% within } \\
\text { group }\end{array}$ & $\begin{array}{c}12 \\
32.4\end{array}$ & $\begin{array}{c}5 \\
13.5\end{array}$ & $\begin{array}{c}6 \\
16.2\end{array}$ & $\begin{array}{c}6 \\
16.2\end{array}$ & $\begin{array}{c}8 \\
21.6\end{array}$ & $\begin{array}{c}37 \\
100.0\end{array}$ \\
\hline $\begin{array}{l}\text { Group 2 (lower } \\
\text { level per- } \\
\text { formers): } \\
\text { - number of } \\
\text { skiers } \\
\text { - } \% \text { within } \\
\quad \text { group } \\
\end{array}$ & $\begin{array}{c}14 \\
30.4\end{array}$ & $\begin{array}{c}8 \\
17.4\end{array}$ & $\begin{array}{c}8 \\
17.4\end{array}$ & $\begin{array}{c}10 \\
21.7\end{array}$ & $\begin{array}{c}6 \\
13.0\end{array}$ & $\begin{array}{c}46 \\
100.0\end{array}$ \\
\hline $\begin{array}{l}\text { Group 3 } \\
\text { (lowest per- } \\
\text { formance } \\
\text { level): } \\
\text { - number of } \\
\text { skiers } \\
\text { - \% within } \\
\text { group } \\
\end{array}$ & $\begin{array}{c}6 \\
24.0\end{array}$ & $\begin{array}{c}6 \\
24.0\end{array}$ & $\begin{array}{c}6 \\
24.0\end{array}$ & $\begin{array}{c}4 \\
16.0\end{array}$ & $\begin{array}{c}3 \\
12.0\end{array}$ & $\begin{array}{c}25 \\
100.0\end{array}$ \\
\hline $\begin{array}{l}\text { Total number of } \\
\text { skiers }\end{array}$ & 32 & 19 & 20 & 20 & 17 & 108 \\
\hline $\begin{array}{l}\% \text { of total } \\
\text { number of } \\
\text { skiers }\end{array}$ & 29.6 & 17.6 & 18.5 & 18.5 & 15.7 & 100.0 \\
\hline
\end{tabular}

Note: Percentage "agree/disagree" or "neither agree nor disagree" in bold script are combined for each group in the text. 
Table 2b: USA "My siblings had great significance for my development as a cross country skier" (question 4)

\begin{tabular}{|c|c|c|c|c|c|c|}
\hline $\begin{array}{l}\text { Likert scale } \\
\text { points }\end{array}$ & $\begin{array}{l}\text { Completely } \\
\text { disagree } \\
\text { (1) }\end{array}$ & $\begin{array}{l}\text { Dis- } \\
\text { agree } \\
\text { (2) }\end{array}$ & $\begin{array}{c}\text { Neither } \\
\text { agree nor } \\
\text { disagree } \\
\text { (3) }\end{array}$ & $\begin{array}{c}\text { Agree } \\
\text { (4) }\end{array}$ & $\begin{array}{c}\text { Completely } \\
\text { agree } \\
\text { (5) }\end{array}$ & Total \\
\hline \multicolumn{7}{|c|}{ Groups of skiers } \\
\hline $\begin{array}{l}\text { Group 1 } \\
\text { (highest per- } \\
\text { formance } \\
\text { level): } \\
\text { - number of } \\
\text { skiers } \\
\text { - \% within } \\
\text { group }\end{array}$ & $\begin{array}{c}3 \\
15.0\end{array}$ & $\begin{array}{c}5 \\
25.0\end{array}$ & $\begin{array}{c}7 \\
35.0\end{array}$ & $\begin{array}{c}2 \\
10.0\end{array}$ & $\begin{array}{c}3 \\
15.0\end{array}$ & $\begin{array}{c}20 \\
100.0\end{array}$ \\
\hline $\begin{array}{l}\text { Group 2 (lower } \\
\text { level per- } \\
\text { formers): } \\
\text { - number of } \\
\text { skiers } \\
\text { - \% within } \\
\text { group } \\
\end{array}$ & $\begin{array}{c}16 \\
23.5\end{array}$ & $\begin{array}{c}13 \\
19.1\end{array}$ & $\begin{array}{c}20 \\
29.4\end{array}$ & $\begin{array}{c}7 \\
10.3\end{array}$ & $\begin{array}{c}12 \\
17.6\end{array}$ & $\begin{array}{c}68 \\
100.0\end{array}$ \\
\hline $\begin{array}{l}\text { Group 3 } \\
\text { (lowest per- } \\
\text { formance } \\
\text { level): } \\
\text { - number of } \\
\text { skiers } \\
\text { - } \% \text { within } \\
\quad \text { group } \\
\end{array}$ & $\begin{array}{c}3 \\
15.8\end{array}$ & $\begin{array}{c}1 \\
5.3\end{array}$ & $\begin{array}{c}5 \\
26.3\end{array}$ & $\begin{array}{c}7 \\
36.8\end{array}$ & $\begin{array}{c}3 \\
15.8\end{array}$ & $\begin{array}{c}19 \\
100.0\end{array}$ \\
\hline $\begin{array}{l}\text { Total number } \\
\text { of skiers }\end{array}$ & 22 & 19 & 32 & 16 & 18 & 107 \\
\hline $\begin{array}{l}\% \text { of total } \\
\text { number of } \\
\text { skiers }\end{array}$ & 20.6 & 17.8 & 29.9 & 15.0 & 16.8 & 100.0 \\
\hline
\end{tabular}

Note: Percentage "agree/disagree" or "neither agree nor disagree" in bold script are combined for each group in the text.

\section{3) Several of my friends were engaged in cross country skiing in my childhood.}

The proportion of those agreeing or completely agreeing with this statement is $64.9 \%$ in Norway, while in the United States it is lower, at $57.0 \%$. 
For Norway, the differences among the performance groups are minimal, while in the U.S., Group 1 stands out with its low score of $45.0 \%$ agreeing or completely agreeing. In contrast, in Norway, Group 1 ranks highest with a figure of $67.5 \%$ who "agree" or "completely agree".

Table 3a: Norway "Several of my friends were engaged in cross country skiing in my childhood" (question 5)

\begin{tabular}{|c|c|c|c|c|c|c|}
\hline $\begin{array}{l}\text { Likert scale } \\
\text { points }\end{array}$ & $\begin{array}{c}\text { Completely } \\
\text { disagree } \\
\text { (1) }\end{array}$ & $\begin{array}{c}\text { Dis- } \\
\text { agree } \\
(2)\end{array}$ & $\begin{array}{c}\text { Neither } \\
\text { agree nor } \\
\text { disagree } \\
\text { (3) } \\
\end{array}$ & $\begin{array}{c}\text { Agree } \\
\text { (4) }\end{array}$ & \begin{tabular}{|c} 
Completely \\
agree \\
(5)
\end{tabular} & Total \\
\hline \multicolumn{7}{|c|}{ Groups of skiers } \\
\hline $\begin{array}{l}\text { Group 1 } \\
\text { (highest per- } \\
\text { formance } \\
\text { level): } \\
\text { - number of } \\
\text { skiers } \\
\text { \% within } \\
\text { group } \\
\end{array}$ & $\begin{array}{c}4 \\
10.8\end{array}$ & $\begin{array}{c}2 \\
5.4\end{array}$ & $\begin{array}{c}6 \\
16.2\end{array}$ & $\begin{array}{c}10 \\
27.0\end{array}$ & $\begin{array}{c}15 \\
40.5\end{array}$ & $\begin{array}{c}37 \\
100.0\end{array}$ \\
\hline $\begin{array}{l}\text { Group 2 (lower } \\
\text { level per- } \\
\text { formers): } \\
\text { - number of } \\
\text { skiers } \\
\text { - \% within } \\
\quad \text { group } \\
\end{array}$ & $\begin{array}{c}5 \\
10.9\end{array}$ & $\begin{array}{c}4 \\
8.7\end{array}$ & $\begin{array}{c}7 \\
15.2\end{array}$ & $\begin{array}{c}19 \\
41.3\end{array}$ & $\begin{array}{c}11 \\
23.9\end{array}$ & $\begin{array}{c}46 \\
100.0\end{array}$ \\
\hline $\begin{array}{l}\text { Group 3 } \\
\text { (lowest per- } \\
\text { formance } \\
\text { level): } \\
\text { - number of } \\
\text { skiers } \\
\text { - \% within } \\
\text { group } \\
\end{array}$ & $\begin{array}{c}5 \\
20.0\end{array}$ & $\begin{array}{c}1 \\
4.0\end{array}$ & $\begin{array}{c}4 \\
16.0\end{array}$ & $\begin{array}{c}8 \\
32.0\end{array}$ & $\begin{array}{c}7 \\
28.0\end{array}$ & $\begin{array}{c}25 \\
100.0\end{array}$ \\
\hline $\begin{array}{l}\text { Total number of } \\
\text { skiers }\end{array}$ & 14 & 7 & 17 & 37 & 33 & 108 \\
\hline $\begin{array}{l}\% \text { of total } \\
\text { number of } \\
\text { skiers }\end{array}$ & 13.0 & 6.5 & 15.7 & 34.3 & 30.6 & 100.0 \\
\hline
\end{tabular}

Note: Percentage "agree/disagree" or "neither agree nor disagree" in bold script are combined for each group in the text. 
Table 3b: USA "Several of my friends were engaged in cross country skiing in my childhood" (question 5)

\begin{tabular}{|c|c|c|c|c|c|c|}
\hline $\begin{array}{l}\text { Likert scale } \\
\text { points }\end{array}$ & $\begin{array}{c}\text { Completely } \\
\text { disagree } \\
\text { (1) }\end{array}$ & $\begin{array}{l}\text { Dis- } \\
\text { agree } \\
\text { (2) }\end{array}$ & $\begin{array}{c}\text { Neither } \\
\text { agree nor } \\
\text { disagree } \\
\text { (3) }\end{array}$ & $\begin{array}{l}\text { Agree } \\
\text { (4) }\end{array}$ & $\begin{array}{l}\text { Completely } \\
\text { agree } \\
\text { (5) }\end{array}$ & Total \\
\hline \multicolumn{7}{|l|}{ Groups of skiers } \\
\hline $\begin{array}{l}\text { Group 1 } \\
\text { (highest per- } \\
\text { formance level): } \\
\text { - number of } \\
\text { skiers } \\
\text { - \% within } \\
\text { group } \\
\end{array}$ & $\begin{array}{c}1 \\
5.0\end{array}$ & $\begin{array}{c}5 \\
25.0\end{array}$ & $\begin{array}{c}5 \\
25.0\end{array}$ & $\begin{array}{c}8 \\
40.0\end{array}$ & $\begin{array}{c}1 \\
5.0\end{array}$ & $\begin{array}{c}20 \\
100.0\end{array}$ \\
\hline $\begin{array}{l}\text { Group 2 (lower } \\
\text { level } \\
\text { performers): } \\
\text { - } \text { number of } \\
\text { skiers } \\
\text { - } \% \text { within } \\
\text { group } \\
\end{array}$ & $\begin{array}{c}10 \\
14.7\end{array}$ & $\begin{array}{c}10 \\
14.7\end{array}$ & $\begin{array}{c}8 \\
11.8\end{array}$ & $\begin{array}{c}20 \\
29.4\end{array}$ & $\begin{array}{c}20 \\
29.4\end{array}$ & $\begin{array}{c}68 \\
100.0\end{array}$ \\
\hline $\begin{array}{l}\text { Group 3 (lowest } \\
\text { performance } \\
\text { level): } \\
\text { - } \text { number of } \\
\text { skiers } \\
\text { - } \% \text { within } \\
\text { group }\end{array}$ & $\begin{array}{c}3 \\
15.8\end{array}$ & $\begin{array}{c}2 \\
10.5\end{array}$ & $\begin{array}{c}2 \\
10.5\end{array}$ & $\begin{array}{c}7 \\
36.8\end{array}$ & $\begin{array}{c}5 \\
26.3\end{array}$ & $\begin{array}{c}19 \\
100\end{array}$ \\
\hline $\begin{array}{l}\text { Total number of } \\
\text { skiers }\end{array}$ & 14 & 17 & 15 & 35 & 26 & 107 \\
\hline $\begin{array}{l}\% \text { of total } \\
\text { number of skiers }\end{array}$ & 13.1 & 15.9 & 14.0 & 32.7 & 24.3 & 100.0 \\
\hline
\end{tabular}

Note: Percentage "agree/disagree" or "neither agree nor disagree" in bold script are combined for each group in the text.

\section{4) My friends have always given me recognition for my efforts in cross country skiing.}

Almost as many in the United States (70.1\%) as in Norway (67.6\%) were in agreement or complete agreement on this statement. These figures represent more than the extent of ski-friends, especially in the USA, and suggest also friends outside sport. Separate performance group figures are not shown due to the great homogeneity of results both within and between the countries. 
Table 4a: Norway "My friends have always given me recognition for my efforts in cross country skiing" (question 9)

\begin{tabular}{|l|c|c|c|c|c|c|}
\hline $\begin{array}{l}\text { Likert } \\
\text { scale } \\
\text { points }\end{array}$ & $\begin{array}{c}\text { Completely } \\
\text { disagree } \\
\text { (1) }\end{array}$ & $\begin{array}{c}\text { Disagree } \\
\text { (2) }\end{array}$ & $\begin{array}{c}\text { Neither } \\
\text { agree nor } \\
\text { disagree } \\
\text { (3) }\end{array}$ & $\begin{array}{c}\text { Agree } \\
\text { (4) }\end{array}$ & $\begin{array}{c}\text { Completely } \\
\text { agree } \\
\text { (5) }\end{array}$ & Total \\
\hline $\begin{array}{l}\text { Number of } \\
\text { skiers }\end{array}$ & 1 & 7 & 27 & $\mathbf{4 2}$ & $\mathbf{3 1}$ & 108 \\
\hline $\begin{array}{l}\text { \% of total } \\
\text { number of } \\
\text { skiers }\end{array}$ & 0.9 & 6.5 & 25.0 & $\mathbf{3 8 . 9}$ & $\mathbf{2 8 . 7}$ & 100.0 \\
\hline
\end{tabular}

Note: Percentage "agree" and "completely agree" in bold script are combined in the text.

Table 4b: USA "My friends have always given me recognition for my efforts in cross country skiing" (question 9)

\begin{tabular}{|l|c|c|c|c|c|c|}
\hline $\begin{array}{l}\text { Likert } \\
\text { scale points }\end{array}$ & $\begin{array}{c}\text { Completely } \\
\text { disagree } \\
\text { (1) }\end{array}$ & $\begin{array}{c}\text { Disagree } \\
\text { (2) }\end{array}$ & $\begin{array}{c}\text { Neither } \\
\text { agree nor } \\
\text { disagree } \\
\text { (3) }\end{array}$ & $\begin{array}{c}\text { Agree } \\
\mathbf{( 4 )}\end{array}$ & $\begin{array}{c}\text { Completely } \\
\text { agree } \\
\text { (5) }\end{array}$ & Total \\
\hline $\begin{array}{l}\text { Number of } \\
\text { skiers }\end{array}$ & 0 & 5 & 27 & $\mathbf{4 6}$ & $\mathbf{2 9}$ & 107 \\
\hline $\begin{array}{l}\text { \% of total } \\
\text { number of } \\
\text { skiers }\end{array}$ & 0.0 & 4.7 & 25.2 & $\mathbf{4 3 . 0}$ & $\mathbf{2 7 . 1}$ & 100.0 \\
\hline
\end{tabular}

Note: Percentage "agree" and "completely agree" in bold script are combined in the text.

\section{DISCUSSION}

\section{The Role and Significance of Siblings}

When well over 3 out of 4 of the Norwegian skiers $(77.8 \%)$ had siblings engaged in sport generally, and that among the U.S. skiers more than 2 of $3(68.2 \%)$ grew up with siblings who were active specifically in cross country skiing, then it would be near at hand to interpret this as a factor leading to success. However, this does not coincide with the perception of the skiers. Only approximately 1 of 3 maintains that their sibling(s) had great significance for their development as cross country skiers (34.2\% in Norway and $31.8 \%$ in the U.S.). Many more appear to have developed very well without significant sibling influence $(47.2 \%$ in Norway, and $38.4 \%$ in the 
U.S.A.). Although the $38.4 \%$ figure for the U.S indicates considerable independence, it pales in comparison with the $47.2 \%$ for Norway. It may well be that the difference in these figures finds its roots in cultural history whereby the development of skiers in the United States is more dependent on a sport-specific role-modelling of siblings in the micro-structure of the family, than in Norway, where the broader cultural anchoring of skiing carries an overarching significance. Notable, however, is that in Norway, the top performance group reports greater sibling impact $(37.8 \%)$ than the other performance levels, whereas in the United States the converse is true, with the top group, at $25.0 \%$, being the lowest. This finding supports the view that at the very highest performance level, siblings do play a positive role. Why such is not the case in the U.S. is a matter for further investigation.

The relatively low influence of siblings found here is not in agreement with the Breivik and Gilberg [6] study of Norwegian world elite athletes, where 2 of 3 allocated great significance to their siblings for their athletic career. Their control group, however, showed a pattern similar to the skiers in the present study. Of additional interest, broadly speaking, is that precisely the same proportion (77.8\%) of the Breivik and Gilberg [6] elite had athletically active siblings, as was found among the Norwegian skiers in the inquiry at hand.

Intuitively there appears to be a contradiction between the athleticism of siblings and the perception of its importance by the skiers in the study. This finding calls for more detailed research on this question.

\section{The Role and Significance of Friends}

When well over half $(57.0 \%)$ of the best cross country skiers in the United States, and close to two out of three (64.9\%) in Norway, had friends in cross country skiing, then this points itself out as an important socialization factor. The friendship group may be viewed as a bearer of the culture of cross country skiing. In view of the Norwegian data on the separate performance groups it was conspicuous that in the U.S. Group 1 only $45.0 \%$ had childhood skiing friends, while the Group 2 figure was $58.8 \%$, and for Group 3 it was $63.1 \%$. For Norway, not only were the group differences smaller; they were in the opposite direction (Group1: 67.5\%, Group 2: 65.2\%, and 
Group 3: 60.0\%). That the Norwegian figures, in general, were higher was expected in view of the greater degree of participation in cross country skiing in Norway. However, to explain the contrary group patterns in the two countries more detailed inquiries are required. It remains to be noted, however, that the highest figure recorded was for the highest performance skiers in the study, Norwegian Group 1, and that this lends credence to the suggestion that this ski-social setting in childhood was not without its constructive impact.

Concerning friends' recognition of the efforts in the sport by the skiers in the study, the figures from the two countries do not vary a great deal. In the overall data, $67.6 \%$ of the Norwegian skiers confirm such recognition, while $70.1 \%$ of the U.S. skiers do so as well. It may be assumed that such recognition has had a positive effect for further efforts, and in this regard the figures reported may be favorably compared with those of Breivik and Gilberg [6] in their study of world elite Norwegian athletes. They found that $61.1 \%$ of their subjects assigned significant impact to their friends for their continued efforts in their sport. The athletes in that study could, performance-wise, best be compared with the top groups in the present study, and particularly with the Norwegian Group 1. In this group, as many as $72.9 \%$ (for the U.S., 70.0\%) reported the appreciation of their friends. The feed-back of friends may thus be seen as a notable factor in the athletic lifecontext of high-level cross country skiers.

\section{CONCLUSIONS}

The results of the parents' status, role, and engagement [6] were shown to have in decisive terms contributed to the creation of what has been termed "athlete families". The confirmation of this is found not only in the high level skiers in the study, but also in the general sport- and ski-specific involvement of siblings. Almost 2 of 3 of the best skiers in the U.S. and Norway, respectively, have siblings who were involved in sport generally or cross country skiing specifically. When, nevertheless, only 1 of 3 in each country assign importance to siblings in their own development as skiers, then questions arise. It is possible that some important psycho/social influences had not been consciously registered; -however in-depth interviews would be required for this to be examined. The Breivik and Gilberg [6] interview study of the very best Norwegian athletes did indicate that 
far more ( 2 of 3 ) indicated that their siblings had had considerable influence. In any case, other investigations concerning the role of siblings in sport show such divergent findings that, as Côté [7] points out, it is incumbent upon the field to pursue further clarification of family dynamics in the athletic arena.

Friends are outside the family, but may still have such an important daily presence that their influence can be expected to have significance. Approximately 6 of 10 respondents in the two countries had friends in childhood who were involved in cross country skiing. In vicinity of two thirds had friends who always acknowledged their efforts in cross country skiing. Of these, about one third of friends in both countries were from outside the sport. This was an unexpected finding, indicating that further research is called for to unravel the implications for skiers of these different friendship groups.

The attention paid to friends in sport has been considerably more extensive in earlier studies than that devoted to the role of siblings, notwithstanding that both groupings represent age-mates, or close to it, in the athlete's intimate circle. In the present sphere of investigation, however, the perspectives and findings remain so diverse that is difficult to extract a clear picture. Future work is necessary to shed light on this sector of the athlete's social context. The present study finds only partial confirmation in the relatively comparable Breivik and Gilberg (6) Norwegian world elite investigation, in the way of a reasonable correspondence vis-à-vis the acknowledgement of friends and its importance for the athletic career.

The broad consequences of the recognitions of the present study direct attention to the necessity of viewing sport in its societal contexts. More specifically, athletic performances may largely be seen as mirroring the total growing-up condition and life situation, and as such can be a measuring rod for a society's social policies. With a well-organized and child/youth-friendly political and economic system, a society will facilitate both broad athletic participation as well as performances at the very highest levels. As evident as this is, it nevertheless must also be recognized that for peak achievements to be reached, sport-specific facilities and organizations, as well as highly educated and experienced coaches are needed.

Although the inquiry at hand supports the findings of other studies referred to and thus strengthens the understanding of the role of the sociological 'primary group' in sport, future investigations in this realm could with advantage focus on other sports with a variety of 
different demands in order to delineate possible sport-specific elements of value in the socialization process of aspiring youngsters. An additional and complementary approach would be to broaden the international comparative perspective to uncover further socio-cultural underpinnings that may be of importance in the developmental voyage of ambitious young athletes.

\section{ACKNOWLEDGEMENT}

The authors wish to express gratitude to Dr. Margarita Vikander for her incisive scholarly critique and contribution to the substantive analysis and presentation form of this inquiry.

\section{REFERENCES}

1. Abernethy B., Wood J. M., Parks S. (1999) Can anticipatory skills of experts be learned by novices? Res. Q. Exerc. Sport. 70: 313-318

2. Babbie E. (1973) Survey research methods. Florence: KY: Wadsworth

3. Bandura A. (1986) Social foundations of thought and action: A social cognitive theory. Upper Saddle River: NJ: Prentice-Hall

4. Bomann-Larsen T. (1993) Den evige sne: En skihistorie om Norge. Oslo: Capellen

5. Bourdieu P., Wacquant L. J. D. (1992) An invitation to reflexive sociology. Chicago: University of Chicago Press

6. Breivik G., Gilberg R. (1999) Hvorfor de beste ble best? Oslo: Norges Idrettshøgskole.

7. Côté, J. (1999). The influence of the family in the development of talent in sport. The Sport Psychologist. 13: 305-417.

8. Ericsson K. A., Krampe A. T., Tesch-Römer C. (1993) The role of deliberate practice in the acquisition of expert performance. Psychol. Rev. 3: 363-406

9. Eriksson S. (2001) Vägen till A-lanslaget. In: Sweden: SVEBI's årsbok Aktuell Beteende- och Samhällsvetenskaplig Idrottsforskning

10. Hellstedt J. C. (1987) Invisible players: A family system model. (1995). In: Sport Psychology Interventions. S. M. Murphy (ed.). Champaign, ILL: Human Kinetics. 117-146

11. Likert R. (1932) A technique for the measurement of attitudes. Archives of Psychology. 22

12. Mordal T. (1989). Som man spør får man svar. Oslo: Tano 
13. Rønbeck N.- F., Vikander N. O. (2010) Select your parents with care! - The role of parents in the recruitment and development of athletes. Acta Kin. Univ. Tartuensis. 15: 62-100

14. Rushall B. S., Vikander N. O. (1987) Behavioral inventories for cross country skiers. Spring Valley, CA: Sports Science Associates

15. Scanlan T. K., Lewthwaite R. (1988) From stress to enjoyment: Parental and coach influences on young participants. In: Competitive sports for children and youth: An overview of research and issues. E. W. Brown, C. F. Branta, (eds.). Champaign, ILL: Human Kinetics. 47-58

16. Stevenson C. L. (1990) The early careers of international athletes. Sociol. Sport J. 7: 238-253

Correspondence to:

Nils Olof Vikander

North Troendelag University College

N-7600 Levanger

Norway

E-mail: Nils.Vikander@hint.no 